\title{
NILAI PENDIDIKAN KARAKTER PADA TARI BEDHAYA CEMPE KARYA WASI BANTALA SEBAGAI PANDANGAN HIDUP MASYARAKAT JAWA
}

\author{
Sawitri \\ Fakultas Keguruan dan Ilmu Pendidikan, Universitas Veteran Bangun Nusantara Sukoharjo \\ putrisawitriku@gmail.com
}

\begin{abstract}
ABSTRAK
Karya tari bedhaya cempe sebuah karya yang difungsikan untuk memperingati natal, karya tari ini diciptakan oleh seniman/ koreografer yang mumpuni dan beliau dosen Isi Surakarta. Dari salah satu karya yang diciptakan penulis tertarik mengungkap tari bedhaya cempe yang dipersembahkan untuk mengagungkan nama Tuhan Yesus, Tuhan untuk umat yang beragama nasrani. Karya tari bedhaya cempe ditarikan oleh delapan orang penari putri. Durasi waktu pementasan lima puluh menit. Bedhaya cempe karya tari moderns yang menggunakan iringan gitar, gamelan Jawa, dan paduan suara. Menggunakan panggung terbuka antara penari dan penonton serta jemaat gereja jaraknya dekat. Tata cahaya yang digunakan adalah lampu sentral dan juga menggunakan penyinaran bawah ( down - lighter ). Karya tari yang bebas dalam gerak dan inovasi serta kebebasan dalam berkreativitas. Tata busana yang dipakai penari tata busana cempe dengan warna hitam dan putih. Bedhaya cempe diungkap secara nilai - nilai pendidikan karakter yaitu 1. Wujud ketaatan kepada Tuhan, 2. Kebersamaan, 3 Kegotong royongan, 4 Kekompakan, 5. Tidak membedakan kasta. Pendidikan karakter yang semua mencerminkan kebaikan dan kepatuhan kepada Tuhan Yesus. Nilai pendidikan karakter pada bedhaya cempe dapat digunakan sebagai pandangan hidup masyarakat Jawa.Bernilai yang dapat diterapkan bagi kehidupan masyarakat Jawa
\end{abstract}

Kata kunci: Nilai, pendidikan karakter, tari, pandangan hidup

\begin{abstract}
The work of the Cempe bedhaya dance is a work that is functioned to commemorate Christmas, this dance work was created by a qualified artist / choreographer and he is a lecturer of contents in Surakarta. From one of the works created, the author is interested in revealing the bedhaya cempe dance, which is dedicated to glorifying the name of the Lord Jesus, God for Christian believers. The work of the Cempe Bedhaya dance is danced by eight female dancers. The duration of the staging time is fifty minutes. Bedhaya Cempe is a modern dance work that uses guitar accompaniment, Javanese gamelan, and choir. Using an open stage between the dancers and the audience as well as close proximity to church congregants. The lighting used is a central light and also uses a down-lighter. Dance work that is free in movement and innovation as well as freedom in creativity. The clothes worn by the small black and white dancers. Bedhaya cempe is expressed in terms of character education values, namely 1. The form of obedience to God, 2. Togetherness, 3 mutual cooperation, 4 cohesiveness, 5. No distinction between caste. Character education which all reflect kindness and obedience to the Lord Jesus. The value of character education in the cempe bedhaya can be used as a view of life for the Javanese community, a value that can be applied to the life of the Javanese community
\end{abstract}

Kata kunci: Values, character education, dance, outlook on life

\section{PENDAHULUAN}

Karya tari modern adalah hasil kreativitas dari seniman / koreografer yang disertai inovasi-inovasi dengan gerakan, tata rias, tata suara bahkan iringan dan tata panggung yang tidak terpakem. Karya tari juga merupakan hasil, cipta , rasa dan karsa manusia yang dituang dalam media gerak yang ritis dan indah (Marhensih, 2019). Tari yang tercipta 
ungkapan pengalaman jiwa dari seniman / koreografer. Jumlah dan iringan serta tata rias dan busana juga hasil kreativitas seniman. Berkarya penuangan ide dapat disesuaikan dengan tujuan dan fungsi karya itu di buat. Karya tari dapat berwujud kelompok putra, kelompok putri bahkan ada juga campuran putra dan putri. Durasi dalam pementasan juga sesuai dengan kebutuhan ada yang 25 menit, 30 menit, 35 menit dan juga bisa 50 menit, satu jam.

Penikmat seni dari semua kalangan apabila karya itu diciptakan untuk pertunjukan kalau bedhaya keraton difungsikan untuk upacara sakral di dalam keraton. Masyarakat tidak dapat melihat apabila tidak ada ijin atau undangan dari keraton, sedangkan karya tari yang di luar keraton untuk tujuan pertunjukan dapat dilihat dan ditonton oleh para masyarakat. Masyarakat Jawa sangat menjunjung budaya karena kesenian khususnya tari karya keraton sebuah maha karya yang adiluhung dan sacral (Hastarini, 2011). Bedhaya yang ada di dalam keraton bedhaya ketawang, bedhaya duradasih, bedhaya sukoharjo, bedhaya kiranaratih, bedhaya tejanata. Pada era globalisasi yang masuk ke Indonesia secara besar - besaran pada tahun sekitar tahun sembilan puluhan dan teknologi dapat bebas masuk akan memberikan cahaya dan nuansa baru dalam kreativitas seni yang penuh inovasi pada tari bedhaya akan tetapi karya bedhaya di luar keraton.

Bedhaya di luar keraton yang berwujud tari sangat banyak selaras berkembangnya budaya yang memberikan seniman dan koreografer dapat bebas berkreativitas. Karya yang diwujudkan dapat berupa tradisi dan modern. Karya tari dapat terwujud dari proses penuangan ide dan gagasan. Kreativitas yang sangat terlihat dari dimunculkan dalam karya tari hal yang ingin dimunculkan dalam suatu proses berkarya salah satu contoh bedhaya cempe.Suatu karya akan memberikan pesan kepada para penikmat seni dan di dalam karya tari pastinya ada hal yang ingin disampaikan oleh seniman / koreografer.

Karya tari bedhaya yang secara sejarah ada dan diciptakan di keraton sebuah karya sakral dan magis. Karya tari yang sangat adiluhung dengan sarat makna. Makna yang ditujukan untuk pedoman yang baik bagi masyarakat (Rahayu, 2015). Masyarakat Jawa mencintai budaya Jawa dan juga berusaha melestarikan dengan adanya sanggar - sanggar tari, padepokan. Kepedulian dalam peeliharaan tari dengan cara terus mencipta dan berkarya. Karya yang salah satu tercipta dari seniman dan koreografer serta beliau dosen ISI Surakarta Wasi bantala membuat karya bedhaya cempe. Bedhaya yang dipentaskan di kegiatan natalan. Peringatan upacara sakral bagi umat kristiani. Upacara yang digunakan untuk ibadah dengan upacara natalan orang Jawa mengatakan.

Penari berjumlah delapan penari putri berpakaian hitam dan putih. Iringan gitar, gamelan Jawa dan juga paduan suara. Durasi kurang lebih lima puluh menit. Pola lantai menyeluruh pada panggung dan depan dari umat dan para tamu undangan. Jarak penari dengan para jemaat dan para tamu undangan dekat. Hal ini membuat kedekatan bahwa tari ini tidak membuat jarak siapapun yang akan melihat, menikmati dan yang akan ikut perayaan natal. Natalan diperingati wujud penghormatan dan juga kepatuhan kepada Tuhan Yesus. Penghormatan dan kekhidmatan para jemaat karena Natalan juga doa maka harus khusyuk. Wasi bantala mengungkapkan dalam gerak-gerak pada tari, bentuk seperti teater yang sangat bagus diperagakan oleh delapan penari putri yang berpakaian hitam putih, kepala cempe. Pengungkapan gerak yang sesuai tema ini menjadi mahakarya yang baik, indah dan penuh inovasi.

Karya dari bedhaya cempe memiliki nilai - nilai pendidikan karakter. Pendidikan karakter yang akan diungkap dalam artikel jurnal ini. Sebuah karya seorang seniman yang kemampuannya tidak dapat diragukan lagi. Karya bedhaya cempe pengabtualisasikan diri dari seniman untuk mengagungkan Tuhan akan tetapi juga karya ini mengandung nilai - 
nilai pendidikan karakter. Hal ini yang akan diungkap oleh penulis artikel dalam tulisan artikelnya dengan judul Nilai pendidikan karakter pada tari bedhaya cempe karya wasi bantala yang digunakan sebagai pandangan hidup bagi masyarakat Jawa.

Pandangan hidup sesuatu hal yang sangat penting untuk kehidupan masyarakat Jawa. Masyarakat yang berpegang pada ajaran kehidupan yang menjunjung budaya Jawa. Pandangan hidup setiap manusia berbeda - beda manusia satu dengan manusia yang lainnya. Pandangan hidup dapat digunakan sebagai keyakinan, pegangan bahkan juga pemikiran. Hasil pemikiran dapat diterima oleh akal dan pikiran dan pemikiran itu diyakini sebuah kebenaran. Kebenaran itu diyakini menjadi sebuah pegangan, pedoman, arahanatau petunjuk yang dapat dikatakan sebagai pandangan hidup. Pandangan hidup dapat diungkap dalam artikel yang dibuat dari penulis. Pandangan yang dijadikan hal sakral karena terkait sebuah keyakinan dan tujuan dalam hidup bermasyarakat.

Karya tari adalah ungkapan ide dan gagasan yang dituang dalam sebuah garapan untuk dapat dipertunjukkan sesuai tujuan seniman / koreografer dalam berkarya. Karya tari juga banyak jenisnya dari kelompok/ tunggal, massal. Karya tari juga ada yang dikategorikan dari kelompok moderat, progresif dan fundamental hal ini ada dalam pengkatagorian dari kelompok tari yang terkhusus pada tari kelompok yang berbentuk bedhaya yang di luar keraton . Bedhayan sebuah karya tari yang ditarikan dari empat, lima orang penari bahkan lebih dan karya tari itu gerak terinspirasi dari gerak bedhaya yang di dalam keraton ( Sawitri, 2020 ).

Karya tari sebuah gerakan tubuh secara berirama yang dilakukan di suatu tempat dan waktu tertentu. Gerak adalah elemen pokok dalam seni tari, di dalamnya terdapat unsur ruang, tenaga, dan waktu. Tari juga sebuah hasil imajinasi dengan berfikir, merespon dan merasakan suatu objek yang tertangkap oleh panca indera. Tari tidak terlepas dari simbol dan makna yang terkandung dalam sebuah tarian. Fungsi dari simbol tari ini adalah menunjukkan ekspresi jiwa dan maksud - maksud tertentu. Simbol dalam tari terbagi menjadi empat, yaitu simbol, gerak , busana, dan tata rias.

Simbol gerak ditunjukkan untuk menyampaikan perasaan atau sebuah cerita yang terkandung. Gerakan tari dilakukan dengan banyak cerita yang terkandung. Gerakan tari dilakukan dengan banyak cara , diantaranya secara lembut gemulai, dinamis, atau patah patah. Gerak tari juga sebuah bentuk simbol tari yang digerakkan dengan lembut gemulai menunjukkan penari menghayati dengan penuh perasaan dan kelembutan. Gerakan tari yang dilakukan secara dinamis, menunjukkan semangat, lincah dan bertenaga. Tari yang digerakkan secara patah - patah menyimbolkan ketegasan dan kekuatan. Hal ini terdiri pada gerak kepala yang menunduk, menengok, berputar dan juga gerak menengadah, ada gerak tangan memutar pergelangan, melenggang dan tangan yang direntangkan, gerak badan antara condong, membungkuk yang tegak dan tegap, gerakan kaki ke kanan, berlari, menggesek.

Karya tari sebuah pikiran, pola gagasan yang dituang dalam sebuah gerak tari. Menuangkan ide dalam sebuah gerakan dan juga dalam sebuah garapan dari iringan, gerak, tata panggung, bahkan tata busana, tata rias. Karya tari juga dari bentuk kata - kata dapat juga disajikan dari gerakan yang ritmis yang mempunyai tujuan untuk menghadirkan sebuah karakter manusia, yang sebagaimana mereka bertindak dan berkarya. Tari juga sebuah gerak yang dibentuk secara ekplisit yang diciptakan manusia dan dapat dinikmati (Putra \& Haryati, 2019). Tari merupakan sebuah gerak yang memiliki lambing-lambang geraknya dengan sadar dirancang untuk kenikmatan serta pada kepuasan dari pengalaman pengalaman ulang, ungkapan , berkomunikasi melaksanakan, serta dari suatu penciptaan bentuk - bentuk dalam bentuk karya. 
Humardani menyatakan bahwa Tari juga sebuah pengucapan jiwa dari gerak gerak yang indah, ungkapan bentuk-bentuk gerak ekspresif yang ritmis (Hadi, 2012). Tari juga merupakan ekspresi jiwa manusia yang dituang dalam sebuah gerak - gerak yang ritmis dan indah. Gerakan dapat dinikmati orang lain dan juga dapat diungkapkan sehingga orang lain memahami pesan yang disampaikan oleh pembuat karya tari. Karya tari ini juga sibolis dari pembuat karya sehingga gerak simbolis dapat tersampaikan oleh para penikmat seni ,dan dapat dihayati oleh para penghayat sehingga dapat memberikan penilaian baik dan buruk dalam sebuah karya tari.

Nilai pendidikan adalah suatu yang diyakini kebenarannya dan mendorong orang untuk berbuat positif di dalam kehidupannya sendiri atau kehidupan berasyarakat. Salah satu persoalan kehidupan yang sering menjadi penceratan persoalan pendidikan. Pendidikan dijadikan usaha manusia untuk membina kepribadian sesuai dengan nilai nilai di dalam masyarakat dan adat istiadat kebudayaan. Istilah nilai - nilai dapat diteukan dalam perbendaharaan dalam bahasa inggris dengan kata value yang digunakan untuk menunjukkan kata benda yang abtrak, yang dapat diartikan sebagai keberhailan dan keberhargaan (worth) atau kebaikan (goodness). Sebagai kadar utu atau sifat penting yang berguna bagi keanusiaan. Nilai dapat juga diartikan kumpulan sikap perasaan ataupun anggapan terhadap sesuatu hal mengenai baik - buruk , benar salah , patut dan tidak patut, ulia hina, penting atau tidak penting (Gusni, 2017).

Nilai pendidikan menurut Soelaeman, bahwa nilai adalah segala sesuatu tentang yang baik atau yang buruk. Nilai sesuatu hal yang dipentingkan manusia sebagai subjek, menyangkut segala sesuatu yang baik atau yang buruk sebagai abtraksi, pandangan atau maksud dari berbagai pengalaman dalam seleksi perilaku yang ketat (USMANA, n.d.).

Darmodiharjo, mengungkapkan nilai merupakan sesuatu yang berguna bagi manusia baik jasmani maupun rohani (Setiadi \& Kolip, 2011). Nilai-nilai merupakan abstraksi dari pengalaman-pengalaman pribadi seseorang dengan sesamanya. Nilai merupakan petunjuk-petunjuk umum yang telah berlangsung lama yang mengarahkan tingkah laku dan kepuasan dalam kehidupan sehari-hari (Soekanto \& Pengantar, 2012). Nilai dapat dikaitkan sebagai sesuatu yang berharga atau berguna bagi kehidupan manusia. Persahabatan sebagai nilai positif tidak akan berubah esensinya manakala keadaan sekitar tidak baik.Pengertian nilai dapat disimpulkan sebagai sesuatu yang positif dan bermanfaat dalam kehidupan manusia untuk dipandang dalam kehidupan bermasyarakat. Nilai disini dalam konsteks etika yang baik dan buruk logika benardan salah, estetika indah dan jelek.

Pendidikan secara etimologis berasal dari bahasa yunani paedagogike yang terdiri atas kata pais yang berarti anak dan kata ago yang berarti membimbing anak. Pendidikan berarti segala usaha orang dewasa dalam pergaulannya dengan anak-anak untuk memimpin perkembangan jasmani dan rohani ke arah kedewasaan. Hakekat pendidikan bertujuan untuk mendewasakan anak didik jika pendidiknya sendiri belum dewasa (Nugroho, 2018). Adler mengartikan pendidikan sebagai proses dimana seluruh kemampuan manusia dipengaruhi oleh pembiasaan yang baik untuk membantu orang lain dan dirinya sendiri mencapai kebiasaan yang baik (Puspitasari, 2016).

Pendidikan sebuah batasan segala sesuatu yang mendidik ke arah kedewasaan, bersifat baik maupun buruk sehingga berguna bagi kehidupannya yang diperoleh melalui proses pendidikan. Proses pendidikan bukan berarti hanya dapat dilakukan dalam satu tempat dan suatu waktu. Eksistensi dan kehidupan manusia, nilai - nilai pendidikan diarahkan pada pembentukan pribadi manusia sebagai makluk individu, sosial, religius dan budaya,. Nilai ada beberapa yaitu nilai religius, nilai kejujuran, nilai toleransi, nilai kerja 
keras, kedisiplinan, proses kreatif, sikap mandiri, demokratis, rasa ingin tahu, dan punya semangat kebangsaan. Selain itu memiliki sikap cinta tanah air, menghargai sebuah prestasi, bersahabat, komunikatif, Cinta damai, suka membaca, peduli pada lingkungan, peduli sosial, dan rasa tanggung jawab.

Karakter adalah tabiat atau kebiasaan atau watak kepribadian mmaupun sifat dari seseorang. Definisi karakter juga akuulasi dari watak atau sifat yang diiliki seseorang yang terbentuk secara tidak langsung dari proses pembelajarn yang dilaluinya. Karakter tidak dibawa sejak lahir melainkan terbentuk dari lingkungan hingga orang - orang yang ada di sekitarnya. Karakter juga sejalan dengan tingkah lakunya, seperti aktivitas dalam bicara yang sopan, suka menolong, pemaaf, pearah, disiplin , jujur, ada juga yang sebaiknya misal jahat, keras, bohong dll (Habibi \& AP, 2015), (Awaru, 2017).

Karakter dapat terbentuk pada dasarnya terbentuk melalui proses pembelajaran yang cukup panjang. Karakter manusia bukanlah sesuatu yang di bawa sejak lahir. Lebih dari itu, karakter merupakan bentukan atau pun tempaan lingkungan dan juga orang orang yang ada di sekitar lingkungan tersebut. Karakter seseorang biasanya akan sejalan dengan perilakunya. Seseorang selalu melakukan aktivitas yang baik seperti sopan dalam berbicara, suka menolong, atau pun menghargai sesama, aka keungkinan besar karakter orang tersebut juga baik, akan tetapi jika perilaku seseorang buruk seperti suka mencela, suka berbohong, suka berkata yang tidak baik, aka keungkinan besar karakter orang tersebut juga buruk.

Pandangan hidup adalah pendapat atau pertimbangan yang di jadikan pegangan ,pedoman ,arahan ,petunjuk hidup di dunia . Pendapat atau pertimbangan itu bukanlah timbul seketika atau dalam waktu yang singkat saja, melainkan melalui proses waktu yang lama dan terus menerus, sehingga hasil pemikiran itu dapat di uji kenyataannya .Hasil pemikiran itu dapat diterima oleh akal, sehingga di akui kebenarannya. Atas dasar itu manusia menerima hasil pemikiran sebagai pengangan, pedoman, arahan atau petunjuk yang di sebut sebagai pandangan hidup .Pandangan hidup ada beberapa pandangan hidup yang mutlak kebenarannya, ideologi disesuaikan dengan norma budaya, pandangan hidup yang relatif kebenarannya.

Pandangan hidup yang diterima oleh sekelopok orang sebagai pendukung suatu organisasi, pandangan hidup dapat dikatakan sebuah ideologi. Pandangan hidup juga terkait dengan cita-cita, kebijakan, usaha, keyakinan dan kepercayaan. Cita - cita yang diinginkan yang dapat dicapai dengan suatu usaha atau perjuangan.Tujuan yang hendak dicapai membutuhkan usaha atau perjuangan dengan kerja keras, yang dapat dilandasi dengan keyakinan dan kepercayaan diukur dengan kemapuan akal, kemampuan jasmani dan kepercayaan kepada Tuhan (Hidayatulloh ST, 2016).

KBBI bahwa, harapan cita-cita adalah keinginan, harapan, tujuan yang selalu ada dalam pikiran. Keinginan atau harapan maupun tujuan merupakan apa yang diperoleh seseorang pada masa mendatang. Cita-cita juga sebuah pandangan masa depan. Pada umumnya cita- cita sebuah garis linier yang makin lama makin tinggi, dengan perkataan lain cita - cita merupakan keinginan, harapan dan tujuan manusia yang makin tinggi tingkatannya. Bahwa sebuah cita - cita juga sebuah angan - angan. Persyaratan kemampuan merupakan sebuah realita dengan masa yang akan datang. Cita - cita ada tiga faktor manusia yang dicita - citakan. Seberapa cita yang hendak dan akan dicapai. Pada faktor kognitif, kepribadian dan juga minat. Faktor dari cita - cita untuk mencapai keinginan yadapat dicapai dari niat manusianya, kondisi atau cara untuk mencapai cita cita, dan tinggi tidaknya cita - cita. 
Dari sebuah cita - cita yang akan dicapai bila menjadi sebuah keyakinan dalam hidup akan menjadi sebuah pandangan hidup yang akan diyakini. Keyakinan terkait pada agama dan dalam pada bedhaya cempe menjadi hal yang pengin diungkap penulis. Hal hal yang baik yang sesuai dengan kehidupan yang sejalan dengan kehidupan manusia yang baik dan bermasyarakat.

Masyarakat adalah suatu kelompok manusia yang hidup secara bersama sama di suatu kelompok manusia yang hidup secara bersama sama di suatu wilayah dan membentuk sebuah sistem, baik semi terbuka maupun semi tertutup ,dimana interaksi yang terjadi di dalamnya adalah antara individu - individu yang ada di kelompok tersebut .

Secara etimologis kata " masyarakat " berasal dari bahasa arab yaitu "musyarak" yang artinya hubungan (interaksi), sehingga definisi masyarakat adalah suatu kelompok manusia yang hidup bersama-sama di suatu tempat dan saling berinteraksi dalam komunitas yang teratur. Komunitas yang teratur dalam kelompok tertentu. Masyarakat hidup berkelompok memiliki tujuan dan juga hidup yang saling berbagi dan saling membutuhkan orang lain. Manusia tidak makluk individu melainkan makluk sosial yang butuh berkelompok, bersosialisasi, dan berkelompok dan dapat memenuhi kebutuhan hidupnya. Masyarakat cenderung mencari teman dan juga saudara sehingga pemenuhan kebutuhan dapat berjalan dan bisa terpenuhi. Masyarakat juga cenderung untuk dapat hidup layak untuk kesejahteraan hidupnya.

Pengertian masyarakat adalah sekumpulan manusia yang relatif mandiri, hidup bersama - sama dalam waktu relatif cukup lama, mendiami suatu wilayah tertentu, memiliki kebudayaan yang sama, dan melakukan sebagian besar kegiatan dalam kelompok manusia tersebut. Menurut harton bahwa manusia tidak dapat bisa untuk memenuhi kebutuhannya sendiri. Manusia membutuhkan orang lain dalam memenuhi kebutuhan hidupnya dan kesejahteraan karena kebutuhan hidup tidak dapat terpenuhi dengan sendirinya (Horton \& Hunt, 1999).

Marion Levy bahwa masyarakat terdapat empat kriteria yang perlu ada agar suatu kelompok meiliki kemampuan untuk bertahan, adanya rekrutmen reproduksi atau kelahiran, sistem tindakan yang bersifat swasembada, kesetiaan pada sistem tindakan (Sunarto, 2005), sedangkan Soerjono Soekamto memiliki ciri bahwa manusia hidup bersama sekurang-kurangnya dua orang, bergaul lama dan berkomunikasi untuk mengatur aturan antar manusia, hidup berkelompok dan membentuk sebuah budaya (Soekanto \& Pengantar, 2012). Masyarakat merupakan juga sekelompok manusia yang telah cukup lama hidup dan bekerja sama sehingga dapat terbentuk organisasi baru yang mengatur setiap individu dalam masyarakat tersebuat dan membuat setiap individu dalam masyarakat dapat mengatur diri sendiri dan berfikir tentang dirinya sebagai satu kesatuan sosial dengan batasan tertentu.

\section{METODE PENELITIAN}

Penulisan jurnal menggunakan metode penelitian kualitatif dengan pengupulan data menggunakan wawancara, observasi dan juga menggunakan study pustaka. Data menggunakan peimlihan data sistem cek dan ricek serta tehnik sampling. Pengambilan dari data yang dikatagorikan pada data primer dan sekunder dan informan dapat juga untuk data tersier serta dapat ditingkatkan menjadi data primer atau sekunder asalkan dapat mengungkapkan data yang valid dan menunjang penulisan, (Upe, 2016). Dari pencarian data di tata dan mendapatkan data diskriptif berupa kata- kata dan ungkapan-ungkapan, termasuk di dalamnya tindakan-tindakan yang dapat diamati dengan menekankan pengembangan pada konsep dan pemahaman pada pola yang ada pada data, 
memperhatikan setting serta makna yang menjadi dasar tindakan partisipan dan memahami keadaan dalam lingkup yang terbatas (Nemuan, 2013)

\section{PEMBAHASAN}

Nilai - nilai pendidikan karakter yang digunakan sebagai pandangan hidup masyarakat Jawa yaitu :

\section{Ketaatan dan kepatuhan kepada Tuhan}

Ketaatan tidak dapat dilepaskan dari iman. Ketaatan juga sebuah bukti dari iman. Ketaatan didasarkan dari motivasi tertentu tetapi tidak ada cara lain untuk mewujudkan iman kecuali dengan ketaatan. Ketaatan dan kepatuhan sikap yang baik dan mulia untuk meuliakan Tuhan. Segala yang ada di bumi ini semua ciptaan Tuhan, sudah seharusnya dan selayaknya Tuhan diuliakan. Di sini ketaatan juga wujud dari seorang uat Tuhan yang butuh kedamaian dalam hidup. Doa juga harus selalu dipanjatkan dan minta ampunan apabila kita berbuat salah. Manusia tempat salah dan dosa dan Tuhan yang muliatempat meminta ampunan. Tuhan yesus dimuliakan umat kristiani dan wujud kepatuhan selalu ada kegiatan keagamaan yang dilakukan oleh umat kristen. Masyarakat Jawa yang memeluk agama kristen ibadat di gereja. Ketaatan umat kristen selalu menjalankan yang menjadi perintah Tuhan dan menjauhi semua dari larangan yang tidak boleh dilakukan oleh umatnya (Miss \& Na'imah, 2017). Kehidupan harus ada keseimbangan antara hidup didunia dan untuk yang di alam kekal. Ketaatan kepada Tuhan untuk diberikan ampunan supaya tidak dapat murka dari Tuhan

\section{Kegotong -royongan}

Kegotong royongan adalah sikap saling bantu dengan sesama supaya pekerjaan yang berat terasa ringan. Kegotong royongan terasa sangat kental pada asyarakat yang hidup di desa sedangkan yang hidup di kota rasa kegotong royongan mulai sedikit pudar. Kehidupan dikota yang lebih keras kehidupannya membuat kemandirian lebih terasa dan di kota dikerjakan minta bantuan orang dan membayar jasannya. Kegotong royongan yang di desa - desa terasa lebih kental seringkali kegiatan bangun rumah, parit, jembatan, jalan yang terkait keperluan kampung.

Kegotong royongan pada masyarakat Jawa sangat dijunjung untuk meringankan kerjaan. Kegotong royongan dapat ditanamkan dan dipopulerkan serta lebih diutamakan untuk kehidupan masyarakat Jawa. Kegotongroyongan pekerjaan yang terasa berat jadi ringan. Rasa kebersamaan akan tercipta dalam kegiatan gotong royong. Habis gotong royong biasanya ada menu yang disuguhkan yaitu ketela rambat, ubi, teh, kopi, gorengan dan untuk makan bersama biasanya sayur lodeh, gudangan, tempe, ikan asin, peyek, kerupuk dan itu dimakan bersama sungguh luar biasa. Dalam kegotong royongan sangat mencerminkan hidup itu saling membutuhkan dan hidup saling memberi serta hidup butuh orang lain.

\section{Tolong menolong}

Manusia diciptakan sebagai makluk sosial dan butuh orang lain, manusia tidak bisa hidup sendiri tampa bantuan orang lain. Hidup saling bantu untuk mengurangi kesulitan orang lain. Sikap tolong menolong dapat ditanamkan untuk bantu sesama. Kehidupan manusia butuh pertolongan dari orang lain. Manusia tidak akan dapat menyelesaikan masalah bila hanya dengan kekuatan sendiri. Kodrat manusia yang diciptakan sebagai makluk sosial akan tetap hidup butuh orang disekitar. Sikap tolong menolong dapat 
menjunjung harkat dan martabat orang lain supaya kehidupan sesama manusia dapat sejahtera.

Tolong menolong di masyarakat Jawa sangat dijunjung karena kehidupan akan menjadi nyaman dan sejahtera apabila hidup dapat saling bantu. Tolong menolong untuk orang lain dapat berwujud dengan waktu, tenaga, pikiran dan juga dana. Menolong adalah ajaran dalam agama supaya menjadi pribadi yang baik. Tolong menolong dapat mewujudkan sikap kedamaian bagi umat manusia, tolong menolong juga sebagai kunci untuk hidup yang tentram. Denagn tolong menolong dapat menjunjung harkat hidup orang banyak. Menolong orang lain akan mendapatkan balasan yang baik dari Tuhan. Meringankan beban orang nantinya akan diringankan bebannya.

\section{Tidak membedakan kasta}

Hidup akan terasa nyaman bila kita dapat hidup di tengah masyarakat. Masyarakat yang hidup tidak mebedakan kasta akan terasa lebih indah dan nyaman. Hidup yang tidak ada perbedaan kasta akan akan menciptakan kenyamanan di masyarakat. Mendiskripsikan orang, yang membedakan etnis, agama dan ras, pendidikan akan membuat ketidaknyamanan manusia dan keharmonisan dalam hidup bermasyarakat. Membedakan kasta akan membuat hidup di masyarakat menjadi tidak tenang. Kehidupan akan beriringan tampa ada perbedaan. Membaur dengan siapapapun akan hidup lebih bahagia. Kebahagiaan dan kenyanyaman dalam persaudaraan akan lebih baik untuk kehidupan di masyarakat.

Hubungan yang baik dengan tidak ada kasta hidup terasa nyaman, masyarakat Jawa akan selalu menepis adanya kasta supaya tidak ada percekcokan walaupun ada kasta di keraton juga tetapi pihak keraton sudah membuka diri juga bergaul dengan masyarakat biasa. Manusia di mata Tuhan sama tidak ada guru, dosen, penjahit, dokter, perawat, pengusaha melainkan hidup bermasyarakat itu sama saja. Kasta sudah sangat harus kita tepis untuk ketentraman hidup dalam masyarakat. Kedamaian negara karena kedamaian rakyatnya.

\section{Kekompakan}

Kekompakan dapat diterapkan dalam segala hal hidup di masyarakat, hidup di kerjaan, di gereja, di tempat lomba misal groub, di organisasi apapun. Kekompakan membuat segala sesuatu akan tercapai dengan maksimal. Kekopakan di manapun dibutuhkan supaya kenyamanan dalam bergaul, bekerja dan berorganisasi akan nyaman. Kompak dalam segi positif untuk kemajuan dalam segala faktor kehidupan. Dalam agama kompak dapat membuat pekerjaan terasa ringan, misal saja mempersiapkan untuk memperingati natalan. Pembagian tugas sangat perlu untuk kelancaran dari semua hal yang disiapkan untuk suatu keberhasilan sebuah peringatan agama. Pembagian tugas dapat bantu selesainya secara maksimal.

\section{Saling menghormati dan menghargai ke sesama}

Hormatilah sesama manusia supaya hidup akan berjalan nyaman. Menghormati orang lain sama artinya menghormati diri sendiri. Menghormati tidak akan merendahkan martabat tetapi malahan menjunjung martabat manusia. Hidup yang nyaman akan membuat kehidupan akan berjalan baik. Enghormati ke yang lebih tua, ke yang muda dan ke yang sesama untuk saling hormat menghormati akan tercipta kehidupan yang tentram. Ketentraman jiwa dan tentram dalam hidup akan tercipta masyarakat dengan kehidupan yang baik. 
Nilai - nilai pendidikan diatas dapat memberikan kehidupan yang harmonis antar kehidupan bermasyarakat. Kehidupan yang nyaman dapat memberikan semakin kuatnya persatuan dan kesatuan bangsa. Masyarakat satu dengan kelompok masyarakat yang lainnya hidup rukun dan hidup tentram. Bersatu padu dalam kebaikan akan menjadikan eratnya tali perdamaian, persatuan dan kesatuan bangsa Indonesia. Misalkan berbeda agama tidak menjadi sebuah permasalahan untuk hidup rukun, yang satu keyakinan agama harus kuat dan rukun juga (Ahmad et al., 2019).

Indonesia negara yang memberikan kebebasan untuk memeluk keyakinan sendiri sendiri. Dengan karya untuk dapat memuliakan Tuhan sebuah perayaaan agama atau memperingati kebesaran agama sangat baik dan dapat dijadikan contoh, hal ini di dalam perayaan natal dalam bedhaya cempeyang dilakukan oleh wasi bantala dapat memberikan contoh positif yang sangat mulia. Berkarya dalam kengagungkan pada perayaan natal yang dittaa, dikreasikan gerak tari, teater, paduan suara dan iringan musik perpaduan gamelan Jawa dan intrumen moders menjadikan kolaburasi yang indah, karya yang sangat bagus dapat menjadi contoh baik dalam memuliakan Tuhan. Dapat ditularkan ke agama lain dalam memuliakan keyakinan dapat dengan gerak tari, musik dan juga berteater.

\section{PENUTUP}

Pada artikel jurnal memberikan contoh kehidupan yang baik pada tari bedhaya cempe. Karya tari yang bebas dalam gerak dan inovasi serta kebebasan dalam berkreativitas. Tata busana yang dipakai penari tata busana cempe dengan warna hitam dan putih. Bedhaya cempe diungkap secara nilai - nilai pendidikan karakter yaitu 1. Wujud ketaatan kepada Tuhan, 2. Kebersamaan, 3 Kegotong royongan, 4 Kekompakan, Saling menghormati dan menghargai 5. Tidak membedakan kasta. Pendidikan karakter yang semua mencerminkan kebaikan dan kepatuhan kepada Tuhan Yesus. Nilai pendidikan karakter pada bedhaya cempe dapat digunakan sebagai pandangan hidup masyarakat Jawa.Bernilai yang dapat diterapkan bagi kehidupan masyarakat Jawa.

Masyarakat Jawa sangat menjunjung dan menghargai sesama manusia dengan kekompakan hidup akan terasa lebih ringan dalam pekerjaan. Pendidikan karakter yang sesuai dengan nilai - nilai luhur akan membuat tatanan kehidupan menjadi lebih baik. Keselarasan keharmonisan hidup dikarenakan rasa saling menghargai, menghormati kesesama. Apalagi dalam kehidupan kesesama dan di agama dan keyakinan, keselarasan hidup dan keselarasan akan membuat kehidupan selaras. Pandangan hidup yang baik dan positif akan membawa kehidupan manusia menjadi lebih baik.

\section{DAFTAR PUSTAKA}

Ahmad, K. H., Sakban, A., \& Sudarto, M. (2019). Bentuk Hidup Akur Beda Agama Antara Islam dan Budha di Desa Mareje Kecamatan Lembar Kabupaten Lombok Barat. CIVICUS: Pendidikan-Penelitian-Pengabdian Pendidikan Pancasila Dan Kewarganegaraan, 7(2), 36-47.

Awaru, A. O. T. (2017). Membangun Karakter Bangsa Melalui Pendidikan Berbasis Multikultural Di Sekolah. Prosiding Seminar Nasional Himpunan Sarjana Ilmu-Ilmu Sosial, 2, 221-230.

Gusni, E. (2017). Nilai-Nilai Dakwah dalam Tradisi Mompindai Sincu Suku Mornene di Desa Lakomea Kecamatan Rarowatu Kabupaten Bombana. IAIN KENDARI.

Sawitri, 2019. Ideologi Bedhayan di Surakarta. Prosiding ofThe Third Internasional Seminar on Recent Language, Literature, and Local Culture Studies.Surakarta $20-21$ 
Sep 2019. BASA 19. Isbn9781631902550 ISBN25937650

Habibi, M. M., \& AP, M. (2015). REVOLUSI PENDIDIKAN KARAKTER BANGSA.

Hadi, Y. S. (2012). Koreografi: Bentuk-Teknik-Isi. Dwi-Quantum.

Hastarini, A. D. (2011). Pergeseran tari bedhaya ketawang (Pergeseran dan Perubahan Tari Bedhaya Ketawang Setelah Keraton Bergabung Dengan NKRI).

Hidayatulloh ST, I. B. M. (2016). Upaya Guru Pendidikan Agama Islam dalam membina akhlak peserta didik di SMA Taruna Dra Zulaeha. Universitas Islam Negeri Maulana Malik Ibrahim.

Horton, P. B., \& Hunt, C. L. (1999). Sosiologi Jilid 1. Jakarta: Erlangga.

Marhensih, S. W. (2019). KARAKTERISASI BEDHAYA TOLU KARYA AGUS TASMAN RANAATMODJO. INSTITUT SENI INDONESIA (ISI) SURAKARTA.

Miss, N. H., \& Na'imah, E. (2017). PANDANGAN ULAMA'MUANG PATTANI TERHADAP HADIS KETAATAN KEPADA PEMIMPIN (Studi Kasus Di Daerah Muang Pattani Thailand Selatan). IAIN Surakarta.

Nemuan, W. L. (2013). Metodologi Penelitian Sosial: Pendekatan Kualitatif dan Kuantitatif, Edisi 7. PT. Indeks.

Nugroho, W. A. (2018). Peranan Pendidikan Keluarga Tentang Kekudusan Hidup Menurut Roma 12: 1-2. Fidei: Jurnal Teologi Sistematika Dan Praktika, 1(2), 185-198.

Puspitasari, E. (2016). Pendekatan Pendidikan Karakter. Edueksos: Jurnal Pendidikan Sosial \& Ekonomi, 3(2).

Putra, I. G. G., \& Haryati, N. M. (2019). Tari Kreasi Genitri: Sebuah Tarian Bernuansa Pendidikan. Segara Widya: Jurnal Hasil Penelitian Dan Pengabdian Masyarakat Institut Seni Indonesia Denpasar, 7(1), 36-44.

Rahayu, F. (2015). Kajian Estetis Koreografis Tari Gambyong Retno Kusumo di Sanggar Soerya Soemirat Kota Surakarta. UNIVERSITAS NEGERI SEMARANG.

Setiadi, E. M., \& Kolip, U. (2011). Pengantar sosiologi: pemahaman fakta dan gejala permasalahaan sosial: teori, applikasi dan pemecahannya. Kencana.

Soekanto, S., \& Pengantar, S. S. (2012). Jakarta. Rajawali Press.

Sunarto, K. (2005). Pengantar sosiologi. Universitas Indonesia Publishing.

Upe, A. (2016). Metode Penelitian Sosial: Filosofi dan Desain Praktis. Kendari: Literacy Institute.

USMANA, M. (n.d.). ANALISIS NILAI MORAL DAN PENDIDKAN TOKOH UTAMA DALAM NOVEL SRI RINJANI KARYA EVA NOURMA DAN KAITANNYA DENGAN PEMBELAJARAN SASTRA DI SMA. 